of cotton. Sometimes, also, it largely decides which part of the country a crop shall be grown in ; for example, tomatoes remain free from disease if grown in the drier parts of the country.

In the short discussion which followed, it was pointed out that the relationship between animals, and particularly insects, and micro-climates had been entirely neglected, although this forms a most interesting and important part of ecological study. It was thought that in future more attention should be given to this aspect. An interesting reference was made to phenological and climatological work carried out at Bath during the War. This has shown that inversions are a normal occurrence in valleys ; during a year at Bath they occurred on each of $1 \dot{3} 0$ nights. Flowering dates in Bath are later in the valley than on the hill until about the hundredth day in the phenological year (occurring in May), when the higher day temperatures compensate for the relative lowness of night temperatures in the valley. A plea was made for the concentration of future research on specific problems and for the avoidance of the collection of long records unless these are required to answer such problems. The need for greater rigour in the use of the terms 'micro', 'local' and 'regional', in connexion with climate, was also stressed.

The chairman, in closing the meeting, regretted the absence of reference to animal ecology, but the scope of the subject made some restriction inevitable and the 'sessile' plant demanded first attention. $\mathrm{He}$ emphasized the need for the concentration of research on specific problems, and hoped that in the future closer co-operation between meteorologists and ecologists would be possible.

W. R. DAY

The following references are of value in connexion with Mr. Manley's and Prof. Brunt's papers :

Manley, G., "Topographical Features and the Climate of Britain" Geog. J., 103, 241 (1944). "The Effective Rate of Altitudina Change in Temperate Atlantic Climates", Geog. Rev., 35. 408 (1945).

Brunt, D., "Some Factors in Micro-Climatology", Quart. J. Roy. Met. Soc., 71, 1 (1945).

\section{MICROBIOLOGY OF RETTING}

$\mathrm{R}$ ETTING is the process by which the pectic material which binds the fibres to the remainder of the flax stem is broken down and the fibres are liberated. When flax is immersed in water the straw becomes softened and the soluble constituents, which include carbohydrates, glucosides and nitrogen compounds, are extracted. These provide abundant food for growth of the micro-organisms naturally present on the flax plant, and a rapid development of the mixed flora is then accompanied by characteristic chemical changes both in the liquid and in the straw. The retting is effected by certain types of bacteria which break down the pectic complex of the middle lamella of the flax plant, the fibre bundles being first separated from each other and from the cortex and then themselves split lengthwise into fibres.

The quality of the fibre produced and the ease with which it is afterwards spun into yarns and fabrics depend in a large measure on the proper control of this process of retting. Thus the superb quality of Courtrai flax was often attributed to the peculiar properties of the waters of the Lys between
Welveghem and Courtrai. Probably, however, it depended much more, as it still depends, on the quality of the Flemish retters, who possess an understanding of flax and its ways acquired through generations of practice in the art.

The work of van Tieghem ${ }^{1}$, of Fribes ${ }^{2}$, and of Beijerinck and van Delden ${ }^{3}$ early indicated that anaerobic spore-forming bacteria (now regarded as strains of Clostridium butyricum) were probably responsible for the retting action in ordinary stagnant rets. Carbone and co-workers ${ }^{4,5,6,7}$ later claimed that Clostridium felsineum, an organism which they isolated from Italian hemp-retting pits, was particularly active in retting and produced fibre of fine quality. Cultures of this organism were added as part of the procedure in the Carbone industrial process for retting flax. Later workers in other Continental countries have noted this organismrecognized by the bright orange colonies which it forms on suitable media-among the flora of anaerobic rets. In the retting process discovered by Rossi and co-workers $8, \theta, 10,11$ in Italy, patented by Rossi ${ }^{12}$, and established for a time industrially at Bonnétable in France (Carter ${ }^{13}$ ), a current of air was blown through the contents of the retting tank during the course of the ret. It was claimed that under these conditions aerobic bacteria were the active retting agents, and cultures of $B$. comesii, a facultative spore-forming bacillus, were added at the beginning of retting to hasten and improve the process.

In order to control the end point of retting and to avoid weakening of the fibre through over-retting, various procedures have been introduced to retard bacterial growth in the later stages of retting. These are all based upon the principle that withdrawal of leach liquor, or periodic replacement of part of the retting liquor with fresh water, removes a large proportion of the nutrient material upon which active bacterial growth depends. There are, in fact, a large number of retting processes, wide differences of opinion as to the relative merits of each process, and constant attempts to introduce improvements. This condition reflects the fact that, in the past, retting has been regarded mainly as an art, improve. ments in the process have been largely empirical, and scientific investigation has been meagre.

Growth of micro-organisms in the retting liquor during an anaerobic ret results in the formation of organic acids, including butyric acid, and at the end of the ret a large volume of a highly polluting and evilsmelling liquor remains for disposal. This problem in disposal has in the past frequently been solved by ignoring its existence, as, for example, in dam-retting in Ireland or in river-retting in Belgium. The growth of popular movements to preserve amenities, and of legislation to restrain those who would despoil them, have, however, assisted the tendency in most countries to replace these comparatively primitive methods by controlled retting in tanks.

These matters were considered at a joint meeting of the Association of Applied Biologists and the Microbiological Panel of the Society of Chemical Industry, held at the London School of Hygiene and Tropical Medicine on April 12, when two papers were read. The first paper was by Mr. T. W. Brandon and Dr. C. B. Taylor on "Recent Developments in the Retting of Flax and Disposal of the Waste Waters" ; the second, by Dr. L. A. Allen, dealt with "Recent Developments in the Microbiology of Retting". These authors described investigations carried out during the War by the Water Pollution 
Research Laboratory of the Department of Scientific and Industrial Research.

To meet the needs of the Services, a number of new factories were erected at which large quantities of flax were retted. Most of these were so situated that the waste liquor from anaerobic retting could not be discharged untreated without causing serious pollution. Preliminary experiments showed, moreover, that treatment of such liquor would be costly and difficult. The investigation, therefore, aimed at developing a new process of retting in which partial treatment of the liquor would enable it to be re-used in the process. It was found that if the liquor was adequately aerated during retting-for example, by means of a current of diffused air-it could be eontinually re-used for retting successive batches of flax. Experiments, both on the semi-scale and on the full scale, showed that at least forty batches of flax could thus be satisfactorily retted without any discharge of waste waters. The liquor remaining for disposal at the end of the series was only two or three times as polluting as the liquor from a single anaerobic ret, and was approximately neutral in reaction and comparatively inoffensive in character.

The part played by micro-organisms in the retting process and in the purification of the liquor was assessed from the results of examination of some three hundred samples of liquor and of flax, taken at various stages during the different experimental rets. The flora which developed, both in the liquor and in the flax, during the course of a ret showed the same general charaoteristics in all the processes investigated. Coliform bacteria consistently formed a high proportion of the total flora and commonly reached numbers of several millions per millilitre of liquor. In some rets Bacterium coli type I was the predominant strain-a matter of considerable interest in showing that so-called 'fæcal' coliform bacteria may sometimes develop prolifically in natural conditions outside the animal body. Streptococci of the Leuconostoc type, spore-bearing anaerobes, and Gram-negative, biochemically inert rods were also invariably found in large numbers. Aeration of the contents of the retting tank with diffused air encouraged the growth of aerobic and facultative organisms, but it was significant that the number of anaerobes still remained high unless the rate of aeration was excessive.

Bacteria capable of causing soft rot of potato increased considerably in numbers during the course of a ret. Results of a detailed investigation by Allen ${ }^{\mathbf{1 4}}$ suggested that organisms with this characteristic were also responsible for the retting action, both types of change being due to a breakdown of the pectic complex of the middle lamella of the plant tissue. In both anaerobic and aerated rets, sporebearing anaerobes appeared usually to be the active agents in retting, and the majority of strains isolated in pure culture from these rets (which were operated at $30^{\circ} \mathrm{C}$.) possessed the characteristics of Clostridium tertium. The count of spore-bearing aerobes was usually negligible, but under conditions of excessive aeration $B$. subtilis appeared in large numbers. This organism was found both to rot potato and to ret flax.

Under anaerobic conditions, growth of microorganisms in the retting liquor resulted in the formation of considerable quantities of organic acids, neutral volatile compounds, and gases. Such liquor could not be used successfully for retting another batch of flax because the accumulation of these metabolic products tended to inhibit further growth of bacteria. Retting action was therefore retarded and eventually stopped. The effect of aeration was to alter the metabolism of the bacteria in the direction of more complete oxidation of the organic matter in the liquor, carbon dioxide and water being formed in place of organic acids and other metabolic products. It was found, in consequence, that in an aerated liquor both the content of organic matter and the polluting strength were reduced by much larger amounts than were usual under quiescent conditions. These findings explained why it was that continuous aeration of retting liquor during the course of a ret enabled the liquor to be re-used for retting subsequent batches of flax, and why it was less acidic and less offensive in character than the liquor from an anaerobic ret.

${ }^{1}$ van Tieghem, P., Bull.Soc. bot. France, 26, 25 (1879), and C.R. Acad. Sci., Paris, 89, 5 (1879). 2 Fribes, quoted by Winogradsky, S., C.R. Acad Sci., Paris, 121,
742 (1895).

'Beijerinck, M. W., and van Delden, A., Arch. neerl. Sci., II, 9 418 (1904).

- Carbone D., and Tombolato, A., Staz. Sper. Agric. Ital., 50, 261 and 563 (1917).

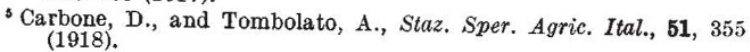

- Carbone, D., Int. Rev. Agric., 10, 477 (1919).

'Carbone, D., and Tobler, F., Faserforsch., 2, 163 (1922)

Rossi, G., Staz. Sper. Agric. Ital., 35, 241 (1902).

- Rossi, G., Ann. Scu. Sup. Agric. Portici, 5 (1904).

${ }^{10}$ Rossi, G., et al., Ann. Scu. Sup. Agric. Portici, 7 (1907).

${ }_{11}$ Rossi, G., and Carbone, D., Ann. Scu. Sup. Agric. Portici, 9 (1909).

${ }^{12}$ Rossi, G., Brit. Pat. No. 6532 (1908).

${ }^{13}$ Carter, H. A., Text. Rec., 37, 127, 171, 229, 368, 41 I (1919).

${ }^{14}$ Allen, L. A., Nature, 153, 224 (1944).

\section{BICENTENARY OF COLIN MACLAURIN, F.R.S.}

O June 14, two hundred years ago, the famous Scottish mathematician Colin Maclaurin died at York, while a guest of Thomas Herring, then the Archbishop of York, and later Archbishop of Canterbury. Maclaurin's death at the early age of fortyeight was indirectly due to the exposure he had suffered while organising the defences of the City of Edinburgh during the Jacobite rebellion of 1745 . At the entry of the rebels into the city, Maclaurin fled to England. In 1733 he had married, and had a family of seven, and from York he wrote that: "Here I live as happily as a man can do, who is ignorant of the state of his family, and who sees the ruin of his country".

Maclaurin was born at Kilmordan, Inverary, in February 1698, being the third son of a minister. Losing both parents at an early age, he was brought up by an uncle and at eleven years of age was sent to the University of Glasgow, where his mathematical talents were soon displayed. At fifteen he took his degree with an essay on gravity. In 1717, when only nineteen, he was chosen professor of mathematics at Marischal College, Aberdeen. Visits to London in 1719 and 1721 made him known to Newton, Dr. Clarke, Martin Folkes and $\rho$ thers and he was admitted a fellow of the Royal Socióty. His academic work was now interrupted by a tour abroad, during which he was tutor to the son of Lord Polwarth, the plenipotentiary of George I. He had already published two works on geometry, and in 1724 he gained a prize from the Paris Academy of Sciences for a memoir on percussion. Returning home, in 1725 he became a candidate for the chair of mathematics at 